\title{
Transparency in the Process of Formation of the Local Administration: A Comparative Legal Analysis
}

\author{
Tatyana Nikolaevna Mikheeva ${ }^{1} \&$ Valentin Viktorovich Kudryavtsev ${ }^{1}$ \\ ${ }^{1}$ Mari State University, Russian Federation \\ Correspondence: Tatyana Nikolaevna Mikheeva, Lenin square, 1, Yoshkar-Ola, 424001, Republic of Mari El, \\ Russian Federation. E-mail: va18882@rambler.ru
}

Received: February 28, 2015

Accepted: April 21, 2015 Online Published: July 30, 2015

doi:10.5539/ass.v11n19p98

URL: http://dx.doi.org/10.5539/ass.v11n19p98

\begin{abstract}
Citizens join the democratic governance mechanisms participating in local governance and solution of local problems. Local administration plays a key role in these processes. The present article considers the main ways of electing mayors, municipal leaders in the USA and the UK. In the study we consider the experience of these countries and development of the local administration institution in Russia. According to the study results the authors made proposals to improve the Russian legislation in order to create additional opportunities for different categories of citizens to influence the process of formation of local authorities.
\end{abstract}

Keywords: local government, municipality, local authorities, local administration, the mayor, "city manager", the head of the local administration, local government authorities

\section{Introduction}

In order for the local government to be a real working system, it is necessary to ensure that the population has the opportunity to make the local authorities work in the interests of citizens. It is extremely important for local communities to control the activities of local government authorities, particularly the activities of the local administration and the head of the municipality (Mikheev, 2014, p. 66) In fact, these representatives of the local authorities carry out municipal policies and make decisions on priorities related to the development of municipalities, solve key economic and business issues. And the most important part of the citizens' control over the activities of local authorities is exercising their right to participate in the formation of government authorities in the municipalities. This is where the principle of transparency, one of the main components in the local government system, is embodied (Mikheev, 2014, p. 103)

It has to be said that the search for an optimal model for the formation of local authorities is particularly important for Russia in frequent changes in the legal regulation of this issue. Meanwhile, these changes cause various estimates made by Russian scientists-constitutionalists, that points up the relevance of the chosen research (Avakyan, 2010, p. 5). In this regard, it is interesting for us to consider the experience of legislative regulation of the formation of local authorities in countries with a centuries-old experience of local government. Russian legislators also took this experience as a basis for the development of the current legal framework in local government.

The objective of our study is to investigate, identify and compare the basic laws, the features of American, British and Russian experience of legal regulation of the processes of election of authorities in municipalities. For this purpose we set the task to determine the basic theoretical principles related to the possible use of American and British experience in local government system in Russia. We have the task to formulate practical recommendations for improving the regulations of the Russian legislation. The present article is devoted to finding the ways to strengthen the democratic principles of democracy at the local level in Russia during the formation of the local administration, as far as the experience in the municipal formation of the USA and the UK is concerned. The authors of the article studied the legal framework of the states and their municipalities, law enforcement practice, statistics.

\section{Methods}

In order to achieve the stated objective of the study both general scientific and specific methods specific to the science of state law have been used. Among general scientific methods the dialectical method has been used. 
This method helps to consider issues under study and other social phenomena. The problem of formation of the local administration has been considered in terms of social, economic and political processes.

The use of the dialectical method allows to consider the importance of the system analysis. With its help we consider the local government institution as being in the single structure of local government. We have studied the participation of political parties and other public associations in the mayoral elections using a synergistic approach

We justified the use of the historical method in our study. This method helps to consider the development of models of the mayoral elections in Russia, the USA and the UK, taking into account the historical features of the legal systems of these countries. The use of the method of logical analysis is important for our study. Using this method we consider the institution of formation of local authorities with similar social processes in other state and social structures, as well as study the degree of their mutual influence in interaction with each other.

The use of the comparative legal method is a key feature of the present study. Using this method, we compare the possibilities of citizens' participation in the mayoral elections in the United States, Great Britain and Russia and study all the factors that affect this process. By applying this method, we derive theoretical principles concerning the use of American and British experience in municipal formation in Russia.

We used the statistical method along with general scientific methods. This method implies reliance on official information. The statistical method is used when considering the structure of the deputy corps of representative bodies and the level of involvement of various public associations in the municipal election process; it is also used in the assessment of local regulations and in the statistics of application of the method of public participation in the formation of representative bodies. Among specific scientific methods the formal-logical method plays the key role. With its help we have developed specific assumptions and mechanisms to improve Russian legislation in the sphere of public participation in the formation of local government and in the mayoral elections.

\section{Results and Justification}

In recent years the following model has spread in Russia: according to this model the city mayor is not elected directly by the public, but approved under the contract from the candidates selected by a special selection board (Kutafin \& Fadeev, 2006, p. 76). Supporters of these changes usually refer to foreign experience, noting that the so-called system of "city management" came into the Russian legal system from the countries belonging to the Anglo-Saxon legal system. Meanwhile, suggesting the foreign experience as a model for the development of local government in Russia, supporters of this model of the mayoral elections does not take into account the historical features of the development of local government in Russia (Avakyan, 2012, p. 7), as well as foreign practice of formation of the "city management" institution.

In fact, this management model is not modern, as commonly assumed. If we interpret the concept broadly, the prototype of the first city manager in Russia was Rurik invited by the Chamber of Novgorod "to reign and rule". In more recent times, in Novgorod there was the practice when they invited the dukes and concluded contracts with them, and if the dukes did not perform their duties well, the Chamber "showed them the way", that means the dukes were simply driven away.

In the modern sense the institution of "city managers" appeared in 1908 in Staunton city, USA. They made a decision to approve the position of General City Manager. At present, the contract management covers about $90 \%$ of the counties and villages of the United States, while in fact it is applied only in a few of them (Prudnikov, 2007, p. 167). In the Russian Federation, the institution of the head of local administration, appointed under the contract, appeared after the Federal Law No. 131-FZ "On general principles of local government in the Russian Federation" entered into force.

Why does this management model continue to be widespread, despite some criticism? What are its advantages?

In the thirties of the twentieth century Lev Velikhov, a renowned expert in the field of municipal government, gave his point of view on choosing the scheme of city management: "It all depends on the candidates chosen for election to local government at the moment. If there is a bright, strong leader, it is reasonable to choose him as a head of the population. If there is no such a leader, it is better to hire a professional manager in order to avoid mistakes in economic sphere" (Velikhov, 1996, p. 96)

Considering the position expressed by Velikhov, it should be noted that even the presence of a bright leader does not guarantee that this person will demonstrate the necessary skills of a manager when he deservedly come to power through fair elections. And considering that the head of the administration manages it under the principle of individual responsibility, effects of low-level professionalism of the head can be quite serious. This is one of 
the main arguments in favor of the mayor-manager appointed under the contract.

In Russia, the question of the introduction of "city management" was raised only in the last decade, whiles the United Kingdom, by contrast, and has refused this scheme in recent years. Since the late 1990s Britain began to abandon the system of city managers in favor of the direct mayoral elections. One of the main reasons was that the absence of a strong leader of the city had led to a slowdown in economic and social development, as well as to confusion in the separation of powers between the city manager and the head of the city council. While the mayor who maintained weekly direct contact with the population that had elected him, could lead to progress. The conservative government supported this trend. Importantly this is not mandatory in the UK-in each city the question of the scheme of election of government authorities was settled by means of a national referendum. Almost all of them have shown that the society prefers to live in the city headed by a mayor with full authority. Stoke-on-Trent was the only city where four years ago residents spoke in favor of the "city manager" system (Pronkin \& Petrunina, 2001, p. 46)

In this regard London is quite an illustrative example. The absence of the unified political leadership and a leader in nineties has led to the situation when the provincial towns began to overtake London in their development. But when in 2000 the city returned to the model of a "powerful mayor" who did not share his powers with the head of the City Council, London has made a great step forward. And today most municipality experts in the UK agree that for the further city development it is preferably to choose a strong leader, elected directly by the public, and a unified team of professionals to avoid conflicts within the administration and city management. The data from various surveys that were conducted recently among residents of the UK municipalities, showed the population opinion that a mayor should be a legitimate person, a strong leader the citizens can trust.

The Local Government Act (2000) in the UK establishes three basic models of the organization of local executive authorities. The model "mayor and executive office" implies the direct election of the mayor, who manages the executive power and appoints two or more assistants, forming "a cabinet". Thus, this model assumes the direct mayoral elections by the population and the appointment of the main assistants by the mayor. At present, this model is the most popular in the UK. The second model "leader-cabinet" implies the election of the chief executive (leader) from among the city council members, while assistants (cabinet) may be appointed either by the leader or by the city council. Accordingly, this model provides the subordination of the executive body of local government to the representative body. Under the model "mayor and manager of the council" the mayor elected by the population shares his executive powers with the manager of the council, who is appointed by the council from among the professional managers. Nowadays this model, which is a form of "city management", turned out to be less common in the UK. In this case, in agreement with the minister responsible for local government issues, there are other options for the organization of executive powers at the local level-up to the preservation of the traditional model.

In most cases, after the experiment with the "city manager" system, the major municipalities of Great Britain and the United States decided to give it up. As practice of these countries has shown, in order to attract partners and investment from other countries and regions, the political cluster in the city should be united. And it should be mentioned that it is impossible to separate the political functions of the leader from the administrative ones. Thus, it appears that the return to the "city management" in the UK is rather unlikely. In the USA the "city manager" model is currently applied mainly in small municipalities, which do not drive the economy forward, but just settlements, where economic performance is the main task (Kovalenko, 2008, p. 43). This system recedes into the past both in the UK and in the larger American municipalities. Each successful city is headed by the powerful mayor elected by the population. Accordingly, as practice of the USA and the UK shows, the "city manager" model is quite an abstract model, which, like any abstract model, looks quite different in reality, not as in theory?

If we talk about the electoral system applied to direct mayoral elections in these states, each state has its own features. Thus, in London at the direct mayoral elections the absolute majority system is applied, in which the candidate who receives more than half of the votes in the first round is elected as the mayor. In case if no candidate receives the necessary number of votes, a second round of election is arranged. The system and the principle of the conduct of the second round of the mayoral elections in London have their own specific character, which is markedly different from those of similar elections in other states. In the mayoral elections in London voters have the opportunity to give not one, but two votes in the ballot. They put the first tick for the candidate that voters would like to see as the mayor, and the second tick for the candidate whose candidacy a voter agrees on, if the main candidate he/she chose loses. In the second round of election, which takes place immediately after the main vote counting, the votes are counted as follows. All the candidates except the two leaders of the first round are deleted from the second column, then the election commission counts how many percent of the votes the candidate who came out in the second round scored as a follow-preferred candidate. 
These data are added to the votes cast for chosen candidates in the first round, and the person elected as the mayor, is determined by the sum of the votes. It should also be noted that in the UK not only citizens having permanent registration in the territory of the municipality, but also all those citizens who are permanent residents of the municipality and can confirm their residence with an appropriate certificate on the tax paid to the local budget, the receipt of payment of utility services or other document, have the right to vote in the election of municipal leaders.

The election systems in major cities of the USA also have their own features. For example, in New York City the candidates of political parties participate in the mayoral elections, and the main fight takes place between the candidates of the two major political parties of the United States-the Republican and Democratic parties. In this case, candidates from both parties pass through serious selection by means of a special system of early voting-"primaries" in which a voter has a real opportunity to know candidates better, to know how close the candidates are to the local population. In addition, it allows to screen out candidates with deliberately populist views, who do not have any program of the city development and pursue purely personal advertising goals.

At the same time, speaking about the USA and the UK, it is necessary to take into account the overall structure and organization of local government, local authorities, which affects the preference and popularity of the model of direct mayoral elections to a certain extent. For example, in the United States the commission system became widespread as it is relevant to small areas, where the solution of economic issues stands first on the list. In smaller towns, the population elects a commission of 3-7 people that perform simultaneously the powers of representative, executive and administrative bodies of local government.

In the cities and larger municipalities of the UK the practice of the special townships and other forms of organization of local authorities has become widespread as in some cases they have functions of local authorities and deal with solution of the issues of improvement of city environment and economic issues relevant for the residents of a particular area. At this level, many issues of daily life of local people are solved. In turn, the mayor acquires the features of a socio-economic and political figure, dealing with the formation of a largely defined concept of socio-economic, administrative, cultural and overall development of the municipality. In this connection, it seems logical that the program on all mentioned issues is to be developed on the basis of interests and opinions of the residents of the municipality. For the same reason the direct mayoral elections are widespread in major US cities (Gabardi, 2001, pp. 547-568.)

The participation of citizens' associations in the direct mayoral elections in the UK and the USA has its own specifics. For example, in the UK the mayoral elections are mostly of a party character, which is largely explained by the developed tradition of political parties culture in this country. In the USA, such kind of elections occurs mainly in large cities. The constitutions of many states prohibit the participation of parties in municipal elections that is why independent candidates and candidates from non-partisan public associations take part in these elections. These features in the USA have their own history: until the last century, political parties used to put forward candidates representing the interests of large financial and industrial lobby that affected the independence of small municipalities not in the best way.

In Russia according to the Federal Law "On general principles of organization of local government" (Federal Law as of 06.10.2003 No. 131-FZ "On general principles of organization of local government in the Russian Federation", 2003) since 2003 there are two models of the mayoral elections. Along with direct elections there is a system in which the head of the municipality is elected from among the members of the representative body, while the head of the local executive and administrative body (City Manager) is approved by the selection board under the contract. Nowadays the latter method is more often considered by regional laws as the only one (Federal Law of the Russian Federation dated May 27, 2014 No. 136-FZ "On Amendments to Article 26 of the Federal Law "On general principles of organization of legislative (representative) and executive bodies of subjects of the Russian Federation" and the Federal Law "On general principles of organization of local government in the Russian Federation ", 2014). The essential difference of this system in Russia from the system previously used in the UK and the USA is a method of formation of selection boards that confirm an appointment of mayors. If in the countries of the Anglo-Saxon legal system using this method of election of the head of the municipality the selection board consists of local deputies with the participation of representatives of civil society, while the Russian legislation actually allows the participation of representatives of public authorities in this process. Thus, in accordance with the latest changes made to the Federal Law "On general principles of organization of local government", the head of the local administration in Russia under the "city management" system is appointed by the local representative body, choosing the candidate proposed by the selection board. This selection board is formed by half of the local deputies-and by half of the number of persons to be appointed by the highest official of the Russian Federation. This system cannot be identified with the 
system of invitation of the duke in Novgorod and Pskov Republics. Any issues associated with the invitation and the exile of the duke was solved by popular assemblies representing all the population. Speaking about the Russian "city management" model that is currently being introduced, the candidate for the head of the municipal administration is actually selected by representatives of the Governor and by a few local deputies.

In turn, the Russian legislation does not stipulate the criteria for selection of members of the selection board. In addition, the procedure for selection is not settled. The citizens and their associations have virtually no opportunity to control the work of the selection board, to understand the criteria for selection of candidates for the post of mayor. In this case the representative body is limited in its choice by only those candidates that are offered by the selection board.

In this case the contract system deprives citizens of their opportunity not only to directly elect the mayor, but also to initiate the voting procedure on his recall, since in this situation the mayor ceases to be an elected official. This puts the residents of these municipalities in an unequal position with those municipalities where the mayors are elected directly and, therefore, citizens have the opportunity to recall the head of the local administration. Here we can see the limitation of the principle of transparency in local government, since transparency suggests the possibility of implementing a real civil and public control over the activities of local government authorities (European Charter of Local Government, 1985)

Speaking about the violation of the principle of transparency in local government under the system of "city management", we should mention one more aspect. The Russian legislation does not provide any guarantees for participation of citizens and public associations in establishing the essential terms of contracts concluded with the heads of local administrations. These terms are often accepted by local deputies without extensive discussion and the terms of these contracts are generally not available to the public.

In practice the appointment of the mayor by the local deputies in Russia cannot be considered as an expression of the will of the citizens. In this case, representatives of only those political parties that have representation in the local deputy council, take part in the appointment of the mayor. Representatives of local opposition in this situation are cut off from the process of formation of the municipal administration.

Opponents of direct mayoral elections in Russia often point to the possibility of various manipulations during the municipal election process with the use of administrative, financial or other resources. Without denying all these shortcomings, which largely reduce the credibility of the elections at all levels, nevertheless, it should be noted that during the direct electoral process such violations are much easier to identify, since the electoral campaign takes place in public. But during the selection of candidates the citizens do not often get this information. In turn, the primary accountability of "city managers" to the selection board and representative body, as well as the dependence of their subsequent appointment on their will, not on the will of the citizens, leads to the fact that in the future activities these mayors shall report to the public authorities of the region involved in the formation of the selection board, but not to the citizens. In this case, on the one hand, we can talk about a decrease in the transparency of activities of the local administration in general, and, on the other hand, about the tendency of nationalization and bureaucratization of local government (Krasnov, 1992, p. 8).

It is important to note that the level of corruption has not become lower in those Russian municipalities where the system of mayors appointment by selection boards had been introduced. But in many of these municipalities there were some cases when the "city managers" were constantly replaced. The Federal Law requires considering the views of local people about the preferences of a particular model of formation of local authorities. However, it does not mean that it is obligatory to obtain the consent of citizens to a particular method of election of representatives of local authorities. So, for the last year direct mayoral elections were canceled in Yaroslavl, Volgograd, Samara regions and some other regions-without any expert opinions and sociological studies to identify the real position of the citizens.

We assume that the rejection of the system of "city management" and a tendency to return to the direct election of the heads of municipalities in the USA and the UK were not accidental. The states that chose the democratic development paradigm and the management decentralization associated with this paradigm, are faced with the need for transparency in local governance (Adams, 2004, p. 273) This implies the implementation of local government available and understandable for the citizens, as well as an access to municipal services. An appropriate model of formation of local government shall contribute to that (Medushevsky, 2014, p. 88). Thus, if we talk about American and British experience of the municipal formation, we assume it is appropriate for Russia to turn to the vector, which is to empower citizens to directly elect the local authorities. At the same time, it seems to us that a number of aspects of the municipal election process, relating to the mayoral elections, should be established taking into account the peculiarities of the current stage of historical development of 
Russia, and we offer the following mechanisms of this process.

We consider it appropriate to enshrine in the Constitution of the Russian Federation (the Constitution of the Russian Federation, 1993) the list of officials in the municipality, who must be elected in direct elections, and to add the heads of local administrations to this list. In addition, it is also necessary to enshrine in the Federal Law "On general principles of organization of local government" one model of elections of the head of local administration. This model involves the conduct of general direct mayoral elections in the municipality, where the candidate who gets the absolute majority of votes, shall be elected. Otherwise, the vote should take place in two rounds. Moreover, a particular model of the mayoral elections should be replaced or established only with the consent of the local population in a local referendum. In order to depolitize the local government and ensure its true independence, political parties should be excluded from among the subjects having the right to nominate candidates for the post of mayor. At the same time it is necessary to confirm the right of the public associations to nominate candidates without collecting signatures (Federal Law "On Public Associations", 1995). These public associations should have their offices in the cities and municipal districts and have the right to participate in solving local issues, enshrined in their statues. The right of citizens to elect the mayor must necessarily be combined with their right to control the transparency of subsequent activities of the mayor (Putnam, 1996, p. 12). Therefore, we consider it appropriate that the elected mayor shall sign a contract not with the representative body, but with the residents of the municipality. The head of the municipality (chairman of the local deputy council) shall be a person who acts upon the signed contract on behalf of the citizens. Thus the procedure for drawing up and signing the contract with the elected mayor should be enshrined in the federal law on local government so that local residents can participate in the discussion of the draft of this contract, and in the future be able to read and understand this contract in the published version-both in the local press and in the system of "e-municipality." In addition, the local community should be entitled to initiate the recall of the mayor in the case of violations and failure of the mayor to perform the terms of the contract.

It is important that not only the election of the mayor, the head of the local administration, but also the election of the team that holds key positions in the local administration should be transparent. For this purpose we propose to enshrine in the federal legislation (Federal Law as of 12.06.2002 No. 67-FZ "On Basic Guarantees of Electoral Rights and the Right of Citizens of the Russian Federation to Participate in a Referendum, 2002) the position, according to which a candidate for mayor must draw up and be on the top of the electoral list of candidates from several candidates for his deputies in the local administration. In turn, the voters will have the opportunity to vote for an open list of candidates for positions in the local government and give their preferences on the basis of prior knowledge of the team, which is headed by the elected mayor. The principle of transparency should be reflected in media coverage of the election campaign for the mayoral elections. It is necessary to enshrine the provision in the federal electoral law that would oblige the regional mass media to provide information platform for campaigning, as well as for debates between the candidates for mayor.

A set of suggested measures is aimed at ensuring the transparency of the process of formation of local government, greater attractiveness and accessibility of local government. The experience of the UK and the USA allows us to talk about the fact that the democratic system of local government where the state bodies do not interfere in the process of election of local governments, is more viable. If we use this experience in Russia at the present stage, it is extremely important to apply such law regulation of local government that would prevent its bureaucratization and help to reduce corruption (Krasnov, 2012, p. 18). In other words, the legislation regulating the local government should promote the spirit of self-government at the local level. And the principle of transparency in local government plays the most important role in this process. In the field of local government election we consider the transparency as a free access of non-party candidates from public associations, capable to engage all the local population into the process of nominating candidates for mayor. The gradual citizens' awareness of their choice, which they carry out in the election of the mayor and his deputies, shall eventually lead to citizens' understanding their responsibility when participating in all forms of democracy.

\section{Conclusion}

The right of citizens and their associations to participate in the formation of local government is one of the most important constituent part of the right to exercise local government. Like other human rights, political ones in particular, this right is influenced by different trends associated with changes in the political, social, economic, cultural and other spheres in the state. We should not forget that local government plays the most important role in the constitutional-legal relations and it is the basic foundation of democracy. On this basis, we believe it is necessary to adhere to a reasonable balance between the political expediency of changing the legal regulation of local government and strict subordination to existing principles of local government. Foreign experience shows that without transparency and accessibility it is impossible to comply with all the other principles of local 
government. During several decades of the twentieth century in Russia historically established traditions of local government had been discontinued. After the adoption of the Constitution of the Russian Federation in 1993 a complex process of revival of these traditions began. Therefore, we assume that currently the most important request of the development of statehood in Russia is to ensure the transparency of local government, as well as in the formation of local authorities. Accordingly, it is essential to provide citizens and their associations with maximum opportunities at every stage of the mayoral elections and to ensure public control of each stage of this process.

\section{Acknowledgements}

The authors express their sincere appreciation and gratitude to the Russian Humanitarian Scientific Foundation for financial support of the research and to the magazine (Asian Social Science) for the opportunity to share ideas presented in our work with foreign colleagues.

The study was funded by the Russian Humanitarian Science Foundation as part of the research project No. 14-33-01255.

\section{References}

Adams, B. (2004, January-February). Public Meetings and the Democratic Process. Public Administration Review, 64(1). http://dx.doi.org/10.1111/j.1540-6210.2004.00345.x

Avakyan, S. (2010). Modern problems of constitutional and municipal formation in Russia. Constitutional and municipal law, 3.

Avakyan, S. (2012). Democracy of protest relations: constitutional and legal dimension. Constitutional and municipal law, 1.

Constitution of the Russian Federation adopted by national voting. (1993, December 12). Russian Newspaper, 237, $1-4$.

Constitutional principles and ways of their implementation: The Russian context: analytical report. (2014). Editor-in-chief Medushevsky, A. Moscow: Institute of Law and Public Policy.

European Charter of Local Government, adopted by the Council of Europe. (1985, October 15). Collection of Legislative Acts of the Russian Federation as of 1985, 36. Art. 4466.

Federal Law "On Public Associations". (1995). Collection of Legislative Acts of the Russian Federation, 21. Art. 930.

Federal Law as of 06.10.2003 No.131-FZ "On General Principles of Organization of Local Government in the Russian Federation". (2003, October 6). Collection of Legislative Acts of the Russian Federation, 40. Art. 3822.

Federal Law as of 12.06.2002 No.67-FZ "On Basic Guarantees of Electoral Rights and the Right to Participate in a Referendum of Citizens of the Russian Federation". (2002). Collection of Legislative Acts of the Russian Federation, 24. Art. 2253.

Federal Law of the Russian Federation No.136-FZ "On Amendments to Article 263 of the Federal Law "On General Principles of Organization of Legislative (Representative) and Executive Bodies of Subjects of the Russian Federation" and the Federal Law "On General Principles of Organization of Local Government in the Russian Federation". (2014, May 27). Russian newspaper (p. 17).

Gabardi, W. (2001). Contemporary Models of Democracy. Polity, 33(4). http://dx.doi.org/10.2307/3235516

Kovalenko, N. (2008). Local government as a form of democracy: the manual. St. Petersburg: SPSUEF.

Krasnov, M. (1993). Introduction to municipal law. Moscow.

Krasnov, M. (2012). The draft Constitution of Russia. Moscow Fond "Liberal Mission".

Kutafin, O., \& Fadeev, V. (2006). Municipal Law of the Russian Federation. Moscow.

Mikheev, D. (2014). Legal analysis of the European charter of the local government in the light of the principle of publicity. Life science journal, 11(6).

Mikheeva, T. (2014). Novels in the legal regulation of local government. Constitutional and municipal law, 9.

Pronkin, S., \& Petrunina, O. (2001). State management of foreign countries. Moscow: Aspect Press.

Prudnikov, A. (2007). Local government in foreign countries. Moscow: UNITY-DANA: Laws and Regulations. 
Putnam, R. (1996). Making Democracy Work. Moscow: Ad Magrinem.

Velikhov, L. (1996). Fundamentals of Municipal Economy: General theory of the city, its management, financing and management methods. Moscow: Science.

\section{Copyrights}

Copyright for this article is retained by the author(s), with first publication rights granted to the journal.

This is an open-access article distributed under the terms and conditions of the Creative Commons Attribution license (http://creativecommons.org/licenses/by/3.0/). 